\title{
Improvements to the Water Quality of the Acidic Berkeley Pit Lake due to Copper Recovery and Sludge Disposal
}

\author{
Christopher H. Gammons ${ }^{1} \mathbb{D} \cdot$ Gary A. Icopini ${ }^{2}$
}

Received: 8 March 2019 / Accepted: 16 December 2019 / Published online: 30 December 2019

(c) The Author(s) 2019

\begin{abstract}
The chemistry and limnology of the Berkeley Pit lake, located in Butte, Montana, have substantially changed during the past 15 years. These changes are due to: (1) a large-scale $\mathrm{Cu}$ recovery project in which deep water was pumped to a $\mathrm{Cu}$ precipitation plant and returned to the surface of the lake; and (2) in-pit disposal of lime-treatment sludge. As a consequence, the lake has shifted from a meromictic to a holomictic state, over $99 \%$ of the dissolved Fe has precipitated as schwertmannite and other ferric solids, the total acidity of the water column has dropped by roughly $35 \%$, and the $\mathrm{pH}$ has risen from about 2.5 to near 4.1. Whereas most of the lake was anoxic prior to 2013 , the water column now contains $>6 \mathrm{mg} / \mathrm{L}$ dissolved oxygen from the lake surface to the deepest levels sampled $(>150 \mathrm{~m})$. Concentrations of several other solutes, including As, $\mathrm{P}$, $\mathrm{Cr}$, and $\mathrm{V}$, have fallen sharply due to adsorption or co-precipitation with $\mathrm{Fe}$, while other species, such as $\mathrm{Al}, \mathrm{Mg}$, and $\mathrm{Mn}$, have increased due to dissolution of solids in the sludge. Although the Cu recovery circuit was discontinued in 2013, in-pit disposal of sludge is expected to continue. The pit water is now close to saturation with basaluminite, and the $\mathrm{pH}$ should remain poised in the range of 4.1-4.5 for many years as Al precipitates out of the water column. Pumping and treating of pit water is set to commence in 2019, and will continue for the foreseeable future. Continued in-pit disposal of sludge should translate into long term water-quality improvement and a decrease in annual lime-consumption costs. Although the Berkeley Pit still has a long ways to go before it will meet water quality standards, it is heartening to mine-water specialists that the pit lake may not be a problem that is "too big to fix".
\end{abstract}

Keywords Butte $\cdot$ Montana $\cdot$ Geochemistry $\cdot$ Basaluminite $\cdot$ Schwertmannite $\cdot$ Lime treatment $\cdot$ Mine lake

\section{Introduction}

In the field of mine-lake research, the Berkeley Pit lake in Butte, Montana, USA, is iconic, both from the point of view of its size ( $>185$ billion L) and the severity of its chemistry. Reviews of mining lakes worldwide (e.g. Blanchette and Lund 2016; Castendyk and Eary 2009; Castro and Moore 2000; Davis and Eary 1997; Gammons et al. 2009a, b; Geller et al. 2013; Miller et al. 1996; Soni et al. 2014) often

Electronic supplementary material The online version of this article (https://doi.org/10.1007/s10230-019-00648-8) contains supplementary material, which is available to authorized users.

Christopher H. Gammons

cgammons@mtech.edu

1 Department of Geological Engineering, Montana Technological University, Butte, MT, USA

2 Montana Bureau of Mines and Geology, Butte, MT, USA consider the Berkeley Pit to be an end-member of poor water quality. The lake's metal toxicity poses a threat to wildlife (two mass fatalities of migratory waterfowl have occurred on the lake, most recently in Dec., 2016, see Robbins 2016), and the lake's location within the city limits of Butte adds to its high profile in the media. Pumping and lime treatment of the Berkeley Pit has commenced (May, 2019) and is projected to continue for the foreseeable future. At the time of this writing, no beneficial "end use" is foreseen for the pit, other than as a sump to collect acidic and metal-rich groundwater associated with the historic mining complex of Butte.

When first described (Davis and Ashenberg 1989; Sonderegger et al. 1987), the Berkeley Pit had a pH of 2.7-3.1 and thousands of $\mathrm{mg} / \mathrm{L}$ of total dissolved metals, including $\mathrm{Fe}$, $\mathrm{Al}, \mathrm{Zn}, \mathrm{Mn}, \mathrm{Cu}, \mathrm{Cd}$, and As. In a more recent paper, Gammons and Duaime (2006) showed that the chemistry of the pit had changed relatively little since the 1980s. However, beginning in the mid-2000s, a massive-scale precipitation of dissolved Fe out of the water column was noticed (Tucci 
and Gammons 2015). This event was attributed to a copper recovery circuit which pumped water from the deep lake and returned it to the surface, allowing oxidation of ferrous to ferric iron. During the period 2013-2016, unstable mine walls forced a suspension in monitoring and lake-sampling efforts in the Berkeley Pit. When monitoring resumed in the summer of 2017 with the help of a specially designed remotely controlled ( $\mathrm{RC}$ ) boat, the $\mathrm{pH}$ of the lake had risen to > 3.0, and by 2018 to > 4.0 (GWIC 2019; Hill et al. 2018). Meanwhile, sometime before Dec., 2016, the color of the lake changed from deep red-brown to blue-green (Fig. 1a, b).

The purpose of this paper is to summarize the various changes in the chemistry of the Berkeley Pit that have taken place since the review of Gammons and Duaime (2006), and to present possible explanations for these changes. Readers are referred to the MWEN special issue on Butte, in which Gammons and Duaime (2006) appeared, for more background on the geology, mining history, and history of flooding of the Berkeley Pit and surrounding underground mine workings. Additional information can be found in other journal articles (Gammons et al. 2003, 2009a, b; Pellicori et al. 2005; Stierle and Stierle 2013), and publications of the Montana Bureau of Mines and Geology (MBMG) (e.g. Duaime et al. 1998, 2016, 2018, 2019). A chronology with detailed notes on field and analytical methods used by the
MBMG for Berkeley Pit sampling between 1982 and 2017 is given in Duaime and McGrath (2019). All field and analytical data for samples of Berkeley Pit water collected since monitoring began in the 1990s are available on the internet (GWIC 2019).

\section{Mine Flooding and Pit Management 2003- 2018}

Table 1 presents a time-line summarizing significant events in the history of the Berkeley Pit. Extensive underground mining of high-grade, polymetallic $(\mathrm{Cu}-\mathrm{Zn}-\mathrm{Ag}-\mathrm{Pb}-\mathrm{Mn})$ veins in the Butte District began in the 1870s and continued through the early 1970s. Open-pit mining of the Berkeley Pit took place between 1955 and 1982, after which the dewatering pumps were shut off and the main mining complex of Butte began to flood. Mining of a nearby deposit to the east named the Continental Pit began in 1980 and continues to this day. At the time of this writing, there appears to be little or no hydraulic connection between the flooded Berkeley Pit and the active Continental Pit (McGivern 2014).

Since the Berkeley Pit is part of the largest superfund site in the nation, the U.S. Environmental Protection Agency (EPA) and Montana Department of Environmental Quality

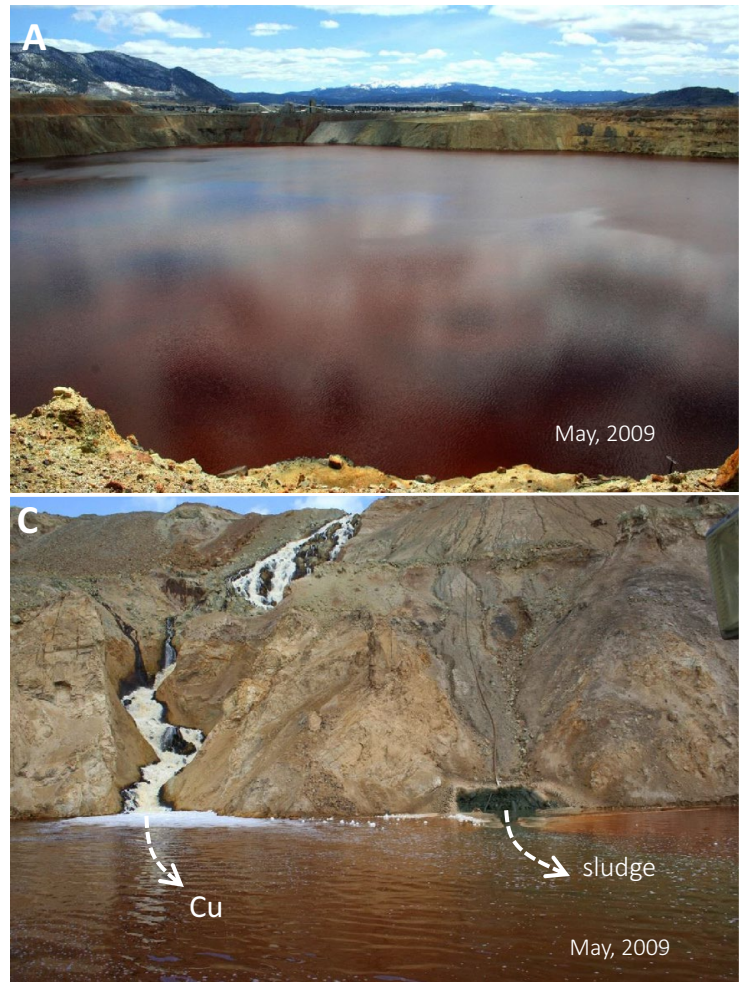

Fig. 1 Photographs of the Berkeley Pit lake: a in May, 2009 (view to south); b in April, 2017 (view to north); c view of return flow from copper precipitation plant ("Cu") and the sludge disposal flow

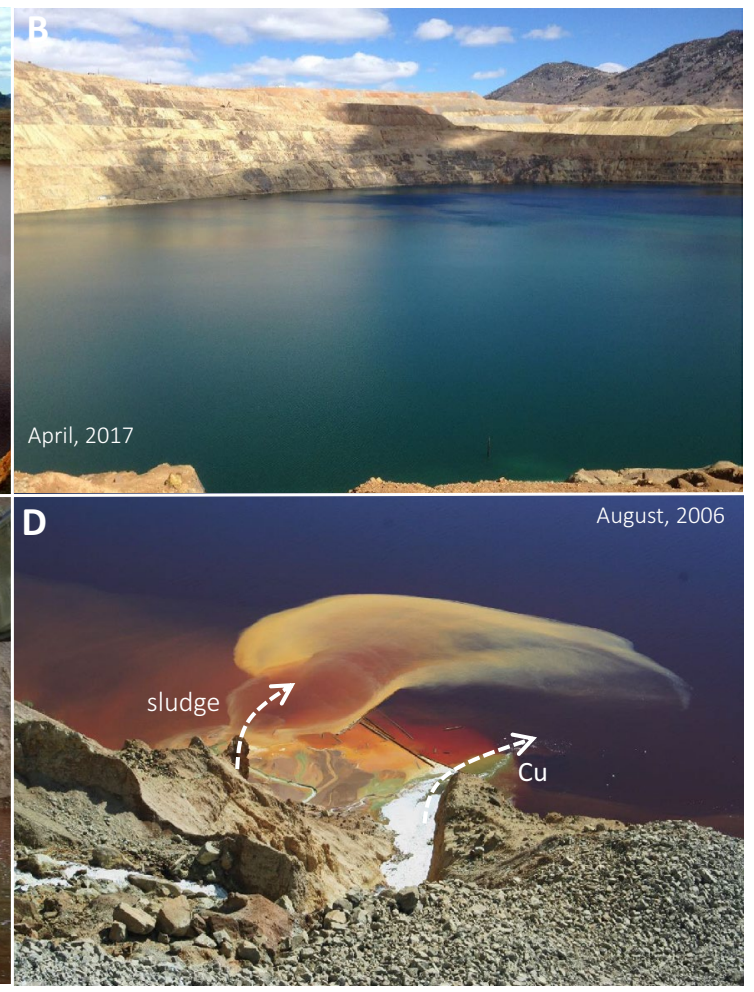

("sludge") from lake level in May, 2009; d same as c, but viewed looking down from the east rim of the pit (August, 2006) 
(DEQ) require semi-annual sampling and profiling of the Berkeley Pit. Until 2013, this work was performed manually with a field crew using a boat to collect samples and data. Several landslides in late 2012 and early 2013 raised concerns for the safety of personnel on a boat during a landslide event. Due to these concerns, manual profiling and sampling of the Berkeley Pit ceased in 2013. In 2015, Montana Resources, Inc. funded Montana Tech to develop a remotely controlled (RC) boat to profile and sample the Berkeley Pit from $1 \mathrm{~m}$ to $200 \mathrm{~m}$ in depth (Fig. 2; Hill et al. 2018). The RC boat successfully collected profile data and samples in July 2017 and thereafter on a semi-annual schedule.

The Berkeley Pit is a terminal lake that is the lowest point in the water table for the entire Butte Summit Valley, with the exception of the bottom of the active Continental Pit (Duaime et al. 2019). The Berkeley Pit continues to fill from a combination of groundwater inputs and precipitation/runoff. In the past, the lake received additional diverted water from the mine complex. The most significant of these in terms of volume is the so-called "Horseshoe Bend springs" (HSB), a collection of acidic springs and seeps draining the active tailings impoundment and heap leach pads to the north and east of the Berkeley Pit (Fig. 3). During the period 2000-2003, the HSB flow was diverted (untreated) to the
Berkeley Pit. Beginning in 2003 to the present day, the HSB flow has been treated with lime and reused by the active mine (Duaime et al. 2016). High-density sludge from the lime-treatment plant is discharged directly to the surface of the Berkeley Pit at a rate of $\approx 0.8-0.9$ million L/day. This flow represents less than $8 \%$ of the total influx of water to the pit, but nonetheless has had a large impact on the lake chemistry, as discussed below. The lime-treatment plant discharges a combination of "Stage 1 sludge" and "Stage 2 sludge". Information on the chemistry and mineralogy of representative sludge samples is provided as a Supplemental Information file.

Another process that has profoundly influenced the chemistry and limnology of the Berkeley Pit is Cu recovery (Duaime and McGrath 2019; Tucci and Gammons 2015). Between 1998 and 2000, and again from 2003 to 2013, the active mining company pumped tremendous volumes (averaging 50 million L/day) of deep-pit water to a Cu-precipitation plant where the acidic water interacted with scrap Fe to form elemental $\mathrm{Cu}$. The reaction, sometimes referred to as cementation, is written:

$$
\mathrm{Cu}^{2+}+\mathrm{Fe}(\mathrm{s})=\mathrm{Cu}(\mathrm{s})+\mathrm{Fe}^{2+} \text {. }
$$

Table 1 Timeline of significant events during mining and flooding of the Berkeley pit lake Modified from Duaime et al. (2016)

\begin{tabular}{|c|c|}
\hline Date & Description \\
\hline 1-July-55 & Mining of Berkeley open pit porphyry copper deposit begins \\
\hline 1-Jan-80 & Mining of Continental open pit porphyry copper-molybdenum deposit begins \\
\hline 22-Apr-82 & Kelley Mine dewatering pumps shut off; mine flooding begins \\
\hline 30-June-82 & Mining of Berkeley Pit ceases; Horseshoe Bend flow (HSB) diverted to Berkeley Pit \\
\hline 30-June-83 & Mining of Continental Pit (CP) suspended. Water from leach pads, precipitation plant and $\mathrm{CP}$ is diverted to Berkeley Pit \\
\hline July-86 & $\begin{array}{l}\text { Montana Resources (MR) resumes mining of } \mathrm{CP} \text { and water pumped out of } \mathrm{CP} \text { is diverted away from the Berkeley Pit for use } \\
\text { in mining operations }\end{array}$ \\
\hline Apr-96 & HSB is diverted away from Berkeley Pit and is pumped to tailings pond \\
\hline Aug-98 & MR begins pumping of Berkeley Pit water for copper recovery \\
\hline 29-Sept-98 & $\begin{array}{l}\text { Major landslide on SE highwall of Berkeley Pit. } 1.0 \times 10^{6} \mathrm{~m}^{3} \text { of material slides into the lake and raises lake level by } 0.76 \\
\text { meters. Probable lake turnover }\end{array}$ \\
\hline 30-Jun-00 & MR suspends mining operations due to rising electricity costs. HSB diverted to pit lake. Copper recovery suspended \\
\hline Jul-00 to Feb 01 & Neutral pH water with low metal concentrations from the $\mathrm{CP}$ is pumped to the Berkeley Pit $(750-1100 \mathrm{~L} / \mathrm{min})$ \\
\hline Nov-03 & MR resumes mining of $\mathrm{CP}$ \\
\hline 17-Nov-03 & $\begin{array}{l}\text { Horseshoe Bend lime treatment plant on line. HSB water is treated and the water is recycled by the mine. High density sludge } \\
\text { is dumped back to Berkeley Pit }(0.8 \mathrm{M} \mathrm{L/day})\end{array}$ \\
\hline Jan-04 & MR resumes pumping of Berkeley Pit water for copper recovery \\
\hline Jan-10 & Copper recovery causes pit lake to shift from meromictic to holomictic state \\
\hline Nov-12 & Landslide damages sample boat and boat dock forcing the cancellation of fall pit sampling and monitoring activities \\
\hline Feb-13 & $\begin{array}{l}\text { Major landslide in SE corner of pit damages copper recovery pipeline; MR suspends copper recovery from Berkeley Pit. } \\
\text { Safety concerns force MBMG to suspend Berkeley Pit sampling/monitoring activities. Lime treatment of HSB water contin- } \\
\text { ues, with sludge disposed in pit }\end{array}$ \\
\hline Nov-Dec-16 & Approximately 10,000 snow geese land on the pit lake, resulting in over 3000 fatalities \\
\hline July-17 & First successful deployment of remotely controlled (RC) boat for vertical profiling and water sampling of Berkeley Pit lake \\
\hline May-19 & Pumping and lime treatment of Berkeley Pit lake begins \\
\hline
\end{tabular}




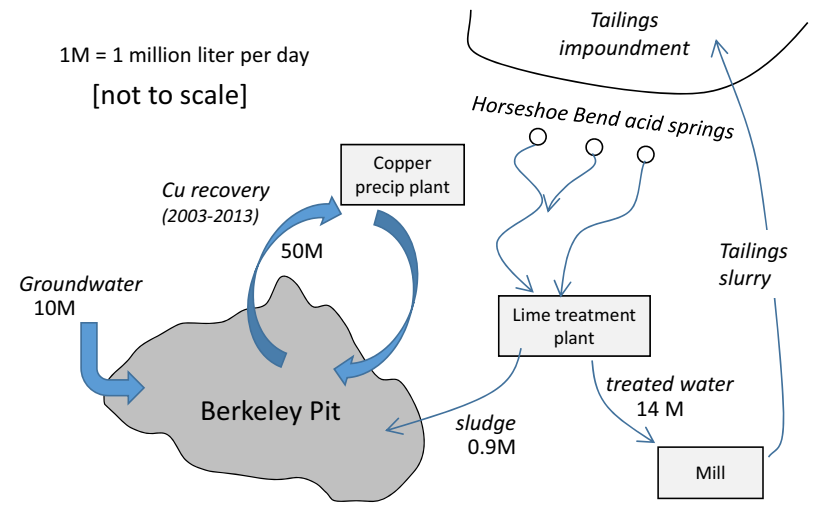

Fig. 2 Schematic diagram (not to scale) showing the flow of surface water and groundwater around the Berkeley Pit during the period 2003-2018. Numbers are approximate flow rates in millions of liters/ day (Montana Resources unpubl. data)

Aside from the changes to the dissolved $\mathrm{Cu}$ and $\mathrm{Fe}$ concentrations, Reaction (1) had no discernable effect on the concentrations of other solutes, nor on the $\mathrm{pH}$ of the water (Gammons and Duaime 2006). The Cu-depleted and Fe(II)enriched water was returned via a ditch to the rim of the Berkeley Pit where it cascaded down the pit wall to mix into the surface of the lake (Figs. 1c, d, 3). Pumping water from the deep lake, passing it through the Cu recovery plant, and returning it to the surface of the lake caused a steady decline in the elevation of the chemocline between the lower TDS mixolimnion from the higher TDS monimolimnion (Fig. 4). By the end of 2009, the chemocline was drawn down to the bottom of the pit and the lake ceased to be meromictic. In Feb., 2013, the $\mathrm{Cu}$ recovery circuit was discontinued due to damage to the pumps from one of the large landslides. In 10 years of operation between 2003 and 2013, the project

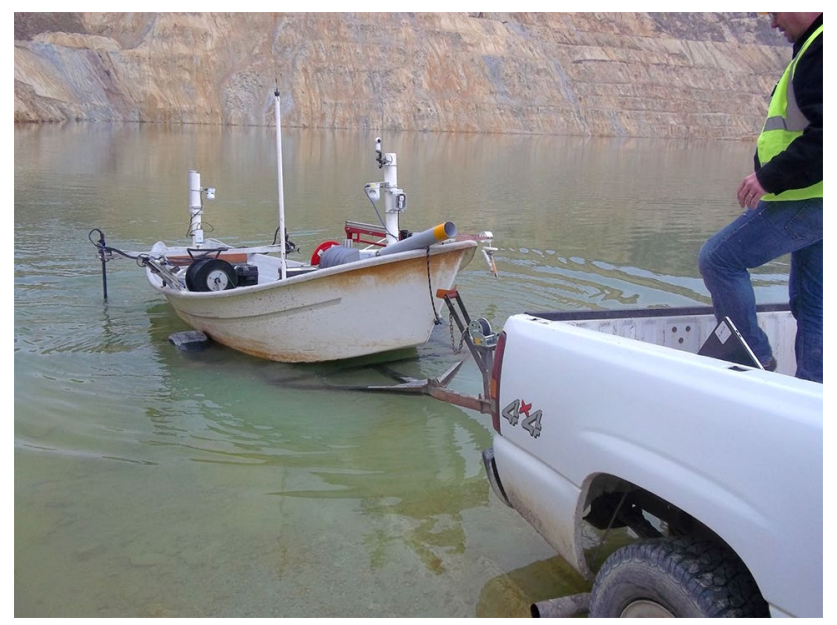

Fig. 3 Photograph of the remotely controlled boat used to sample and profile the Berkeley Pit circulated $\approx 1.5$ pit volumes through the precipitation plant and recovered over 15 million $\mathrm{kg}$ of copper.

\section{Changes to Chemistry}

Figures 5 and 6 summarize changes in selected chemical attributes of the Berkeley Pit with time and depth, respectively. Prior to the suspension of conventional sampling in Nov., 2012, the pH of the pit water varied between 2.4 and 3.0, and there were no clear trends in $\mathrm{pH}$ with time or depth (Fig. 5a). When sampling resumed in 2016, the pH of the surface of the lake had risen to $>3.4$ (Duaime et al. 2018), and by Nov., 2018 the $\mathrm{pH}$ of the lake was $4.1 \pm 0.1$ from top to bottom (Figs. 5a, 6a). Remarkably, between 2003 and 2018, the concentration of total dissolved Fe in the deep lake dropped from $>1000$ to $<10 \mathrm{mg} / \mathrm{L}$. The drop in $\Sigma \mathrm{Fe}$ also decreased the total acidity of the pit lake (Fig. 5c); acidity values were calculated from published chemical analyses of pit-lake water samples (GWIC 2019), as follows:

$$
\begin{aligned}
\Sigma \text { Acidity }(\mathrm{mol} / \mathrm{L})= & m \mathrm{H}^{+}+2 \mathrm{x}\left(m \mathrm{Fe}^{2+}+m \mathrm{Cu}^{2+}\right. \\
& \left.+m \mathrm{Mn}^{2+}+m \mathrm{Zn}^{2+}\right)+3 \mathrm{x}\left(m \mathrm{Fe}^{3+}+m \mathrm{Al}^{3+}\right) .
\end{aligned}
$$

Part of the scatter in the acidity graph is due to uncertainty in the relative concentrations of $\mathrm{Fe}$ (II) and Fe(III) for a given sampling date. For dates when no Fe speciation data

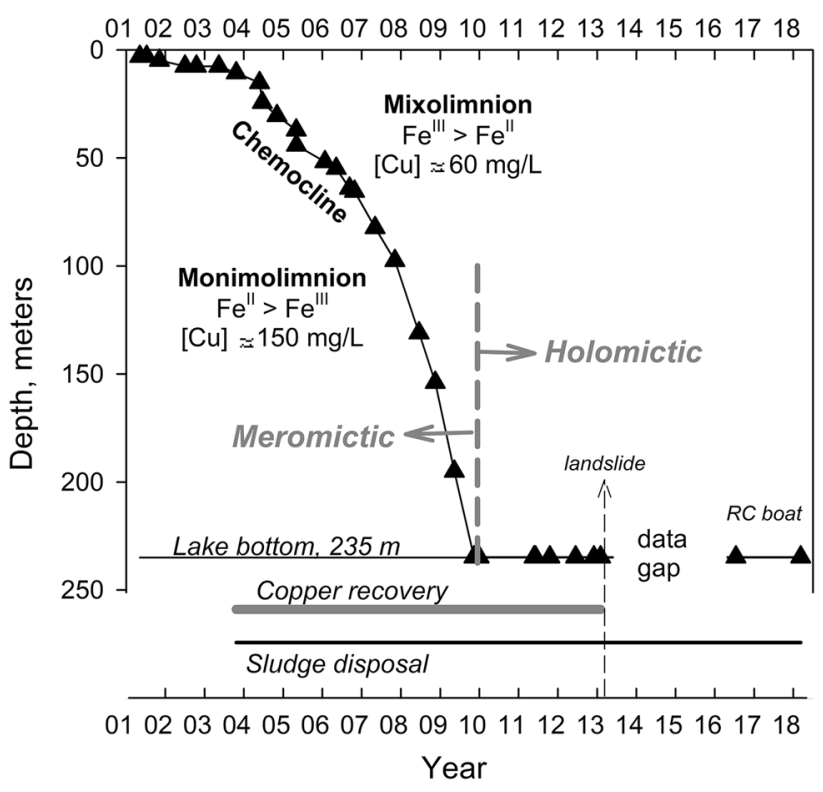

Fig. 4 Diagram showing drawdown in the elevation of the chemocline over time and periods of copper recovery and sludge disposal. Once the chemocline was drawn down to the bottom of the pit (in early 2010), the lake transitioned from a meromictic to a holomictic state 
were available, the valence of dissolved Fe was assumed to be $80 \%$ ferrous for the deep water, and $20 \%$ ferrous for the shallow water. These ratios are based on historical trends (Montana Resources Inc., unpublished data). Pellicori et al. (2005) provide a more detailed discussion of dissolved Fe speciation in the Berkeley Pit.
As would be expected, the precipitation of $>99 \%$ of the dissolved $\mathrm{Fe}$ out of the water column resulted in a decrease in specific conductance (Fig. 6b). Unexpectedly, the pit lake now contains elevated dissolved oxygen (DO) from top to bottom (Fig. 6c). Prior to 2012, concentrations of DO were below the practical quantification limit at all depths below the zone of wave mixing. Since 2017, DO concentrations
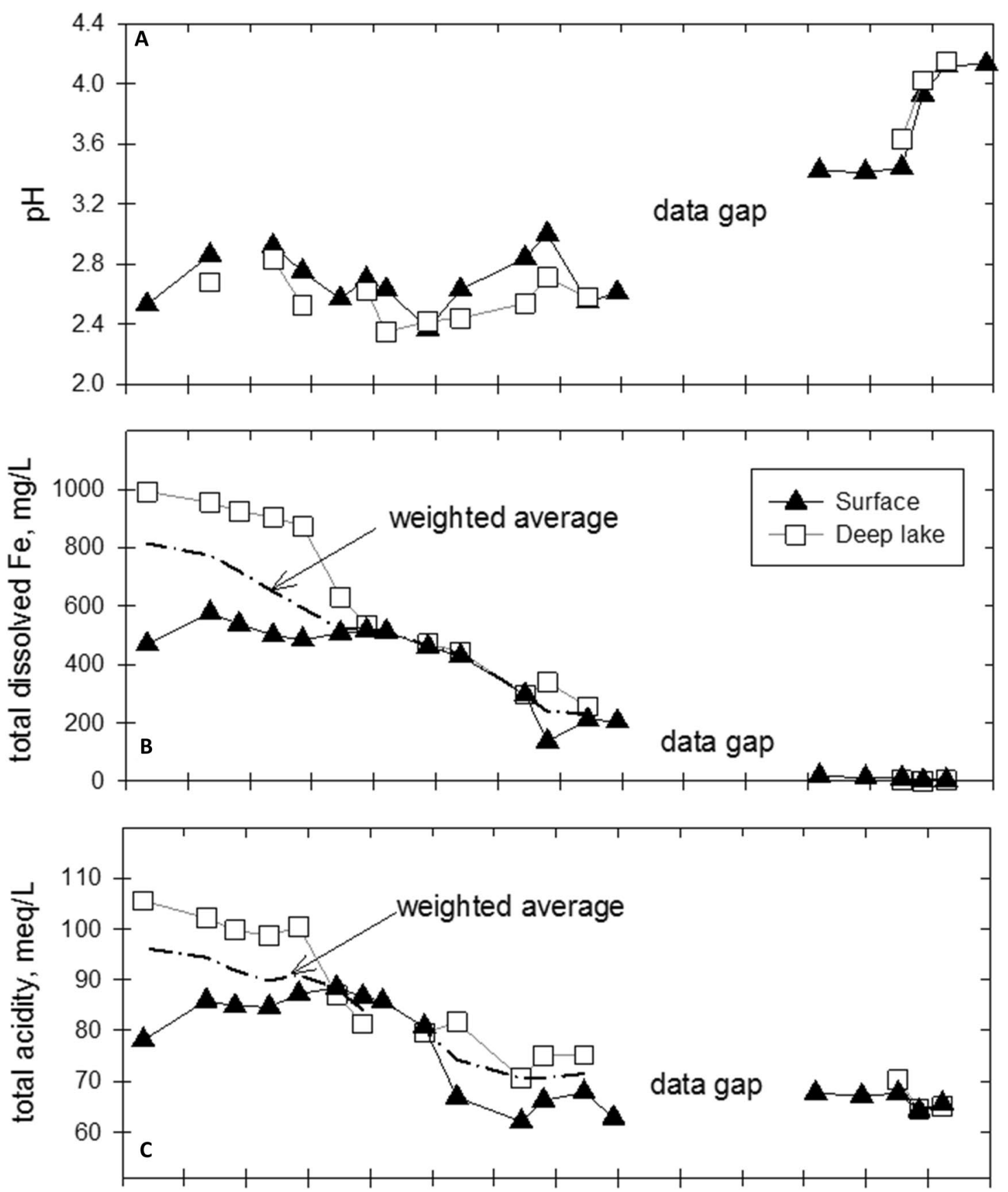

200520062007200820092010201120122013201420152016201720182019

Fig. 5 Changes in $\mathrm{pH}$, total dissolved Fe concentration, and total acidity of the Berkeley Pit lake over time. Filled triangles represent near-surface water; open squares represent deep water (below the chemocline, if present) 

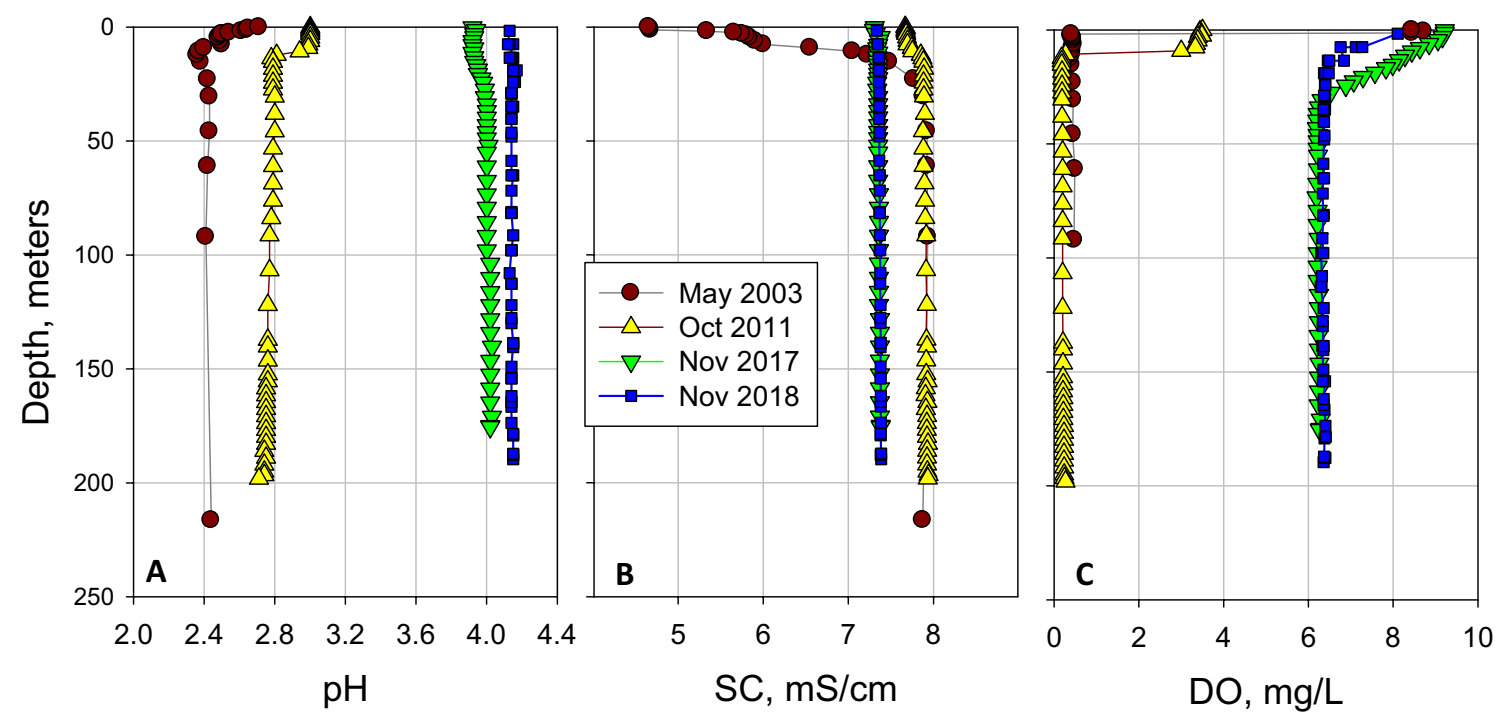

Fig. 6 Depth profiles showing changes in pH, specific conductance (SC), and dissolved oxygen (DO) for selected dates from 2003 to 2018

have been poised at $6.2 \pm 0.2 \mathrm{mg} / \mathrm{L}$ in the deep lake. It is not known if there is a drawdown in DO concentration during the stratified seasons of mid-summer or mid-winter, as sampling of the Berkeley Pit is typically conducted in late spring or late autumn when the lake is most likely to be vertically mixed.

\section{Chemical Behavior of Individual Solutes}

Table 2 provides a recent chemical analysis of the Berkeley Pit water for a sample collected at $67 \mathrm{~m}$ depth on 11/20/18. Figures 7 and 8 summarize changes in the concentrations of selected solutes ( $\mathrm{Fe}, \mathrm{Cu}, \mathrm{Zn}, \mathrm{Al}, \mathrm{Mg}, \mathrm{Ca}, \mathrm{SO}_{4}, \mathrm{As}$, and $\mathrm{P}$ ) with depth and time in the Berkeley Pit; the following sections give a more detailed discussion of each solute. The discussion incorporates results of geochemical modeling using Visual Minteq, v. 3.0 (Gustafsson 2012), a recent variant of the original MINTEQA2 program developed by the U.S. EPA (Allison et al. 1991). More details on the methods and results of the geochemical modeling can be found in the Supplementary Information file.

\section{Iron}

In 2002, the deep Berkeley Pit contained roughly $1000 \mathrm{mg} / \mathrm{L}$ of dissolved Fe (Fig. 7a), most of which was Fe(II) (Pellicori et al. 2005). In contrast, samples collected in March 2018 contained $<5 \mathrm{mg} / \mathrm{L}$ of total dissolved Fe to a depth of $137 \mathrm{~m}$. Thus, in 15 years, $>99 \%$ of the dissolved Fe in the pit lake precipitated out of the water column. Imhoff sediment samplers deployed in 2008 showed that most of the Fe-rich solid was schwertmannite, with lesser amounts of K-jarosite (Tucci and Gammons 2015). The mass of Fe precipitated out of the water column between 2002 and 2018 is estimated at roughly $2 \times 10^{8} \mathrm{~kg} \mathrm{Fe}$. Roughly $10 \%$ of this total came from $\mathrm{Fe}(\mathrm{II})$ generated at the precipitation plant by Reaction (1), with the remainder being equivalent to the total load of dissolved $\mathrm{Fe}$ in the water column in 2002. In addition, a considerable amount of $\mathrm{Fe}$ in the form of ferric hydroxide was added to the lake by disposal of lime-treatment sludge. Like the precipitates that formed in situ, any ferric solids in the sludge would have settled to the bottom of the lake.

Samples collected in Nov. 2017 and March 2018 were found to contain negligible dissolved $\mathrm{Fe}(\mathrm{II})$ at depths to $140 \mathrm{~m}$ (unpublished MBMG data), as might be expected from the presence of DO at all depths. Iron in samples collected in Nov 2018 was primarily Fe(III) at depths of 1 and $17 \mathrm{~m}$, but switched to $\mathrm{Fe}(\mathrm{II})$ at 67 and $139 \mathrm{~m}$. More frequent sampling at additional depths is needed to draw firm conclusions on the current redox behavior of the dissolved Fe.

\section{Copper and Zinc}

Concentrations of dissolved $\mathrm{Zn}$ have been remarkably constant ( $\approx 600 \mathrm{mg} / \mathrm{L}$ ) over time since 2002 (Fig. 7d). In contrast, 10 years of pumping and $\mathrm{Cu}$ recovery between 2003 and 2013 lowered $\mathrm{Cu}$ concentrations from $\approx 160$ to $\approx 60 \mathrm{mg} / \mathrm{L}$ (Fig. $7 \mathrm{c}$ ), where they have remained to the present day. It is not obvious why $\mathrm{Zn}$ and $\mathrm{Cu}$ concentrations should be poised at 600 and $60 \mathrm{mg} / \mathrm{L}$, respectively. Based on Visual Minteq modeling, there are no common $\mathrm{Zn}$ (II), $\mathrm{Cu}(\mathrm{II})$, or $\mathrm{Cu}(\mathrm{I})$ solid phases close to saturation in the pit water. Also, sorption reactions cannot be the primary control on dissolved $\mathrm{Zn}$ and $\mathrm{Cu}$ concentrations, for two reasons. First, until recently, the $\mathrm{pH}$ of the pit water has been too low to expect much sorption of $\mathrm{Cu}^{2+}$ or $\mathrm{Zn}^{2+}$. In the future, 
Table 2 Chemical analysis for Berkeley Pit sample collected on 11/20/2018

\begin{tabular}{|c|c|c|}
\hline \multicolumn{3}{|l|}{ Field readings } \\
\hline Time & & 13:56 PM \\
\hline Depth, m & & 67 \\
\hline pH (s.u.) & & 4.14 \\
\hline Temp ${ }^{\circ} \mathrm{C}$ & & 3.95 \\
\hline $\mathrm{DO}, \mathrm{mg} / \mathrm{L} \mathrm{O}_{2}$ & & 6.37 \\
\hline Eh, mV & & 744 \\
\hline $\mathrm{SC}, \mathrm{mS} / \mathrm{cm}$ & & 7.37 \\
\hline \multicolumn{3}{|l|}{ Major solutes, mg/L } \\
\hline $\mathrm{Al}$ & & 314 \\
\hline $\mathrm{Ca}$ & & 457 \\
\hline $\mathrm{Mg}$ & & 631 \\
\hline $\mathrm{Na}$ & & 76 \\
\hline $\mathrm{K}$ & & 10.6 \\
\hline $\mathrm{Fe}$ & & 1.62 \\
\hline $\mathrm{Mn}$ & & 279 \\
\hline $\mathrm{Zn}$ & & 617 \\
\hline $\mathrm{SiO}_{2}$ & & 123 \\
\hline $\mathrm{Cl}^{-}$ & & 19.5 \\
\hline $\mathrm{SO}_{4}^{2-}$ & & 6872 \\
\hline $\mathrm{F}^{-}$ & & 38.2 \\
\hline $\mathrm{NO}_{3}-\mathrm{N}$ & & $<0.2$ \\
\hline $\mathrm{PO}_{4}-\mathrm{P}$ & & $<0.1$ \\
\hline \multicolumn{3}{|l|}{ Trace solutes, $\mu \mathrm{g} / \mathrm{L}$} \\
\hline As & & 5.6 \\
\hline $\mathrm{Ba}$ & & 7.9 \\
\hline $\mathrm{Be}$ & & 82.6 \\
\hline B & & 65.6 \\
\hline $\mathrm{Cd}$ & & 2130 \\
\hline $\mathrm{Ce}$ & & 676 \\
\hline $\mathrm{Cr}$ & & 3.7 \\
\hline Co & & 1810 \\
\hline $\mathrm{Cu}$ & & 62,000 \\
\hline $\mathrm{La}$ & & 182 \\
\hline $\mathrm{Pb}$ & & 9.5 \\
\hline $\mathrm{Li}$ & & 306 \\
\hline Mo & & 5.7 \\
\hline $\mathrm{Ni}$ & & 1383 \\
\hline $\mathrm{Nd}$ & & 337 \\
\hline $\operatorname{Pr}$ & & 95 \\
\hline $\mathrm{Rb}$ & & 56.4 \\
\hline $\mathrm{Ag}$ & & $<1$ \\
\hline $\mathrm{Se}$ & & 22.1 \\
\hline $\mathrm{Sr}$ & & 1220 \\
\hline $\mathrm{Ti}$ & & 88.6 \\
\hline $\mathrm{U}$ & & 614 \\
\hline Dissolved organic carbon: $1.3 \mathrm{mg} / \mathrm{L}$ & Acidity (pH 4.5): $1420 \mathrm{mg} / \mathrm{L} \mathrm{CaCO}_{3}$ & Acidity (pH 8.3): $3954 \mathrm{mg} / \mathrm{L} \mathrm{CaCO}_{3}$ \\
\hline
\end{tabular}

${ }^{\mathrm{a}}$ Source: GWIC (2019) 
some sorption of $\mathrm{Cu}^{2+}$ onto schwertmannite could take place as $\mathrm{pH}$ values rise above 4.0 (Swedlund and Webster 2001). More importantly, if $\mathrm{Cu}$ and $\mathrm{Zn}$ were sorption-controlled, then their dissolved concentrations should have decreased as $\mathrm{pH}$ of the lake increased from 2.6 to $>4.0$, bearing in mind the $\mathrm{pH}$ sensitivity of sorption of metal cations onto hydrous metal oxide surfaces (e.g., Dzombak and Morel 1990). It is more likely that the concentrations of $\mathrm{Cu}$ and $\mathrm{Zn}$ are sourcecontrolled. That is, there is a more or less constant influx of $\mathrm{Cu}$ and $\mathrm{Zn}$ to the lake from influent groundwater, pit-wall runoff, and dissolution of soluble salts as the lake levels rise, but there is no chemical "sink" for these metals.

\section{Aluminum and Magnesium}

Concentrations of dissolved $\mathrm{Al}$ and $\mathrm{Mg}$ increased significantly between 2006 and 2017 (Figs. 7b, 8a), presumably due to dissolution of solids in lime-treatment sludge which contains $>2$ wt $\% \mathrm{Al}$ and $>3$ wt $\% \mathrm{Mg}$ (see supplementary information file). At $\approx 320 \mathrm{mg} / \mathrm{L}$, the current concentration of dissolved $\mathrm{Al}$ is close to equilibrium with basaluminite $\left(\mathrm{Al}_{4}(\mathrm{OH})_{10} \mathrm{SO}_{4}\right)$ (S.I. $=-0.16$, based on Visual Minteq modeling), and is supersaturated with respect to alunite $\left(\mathrm{KAl}_{3}\left(\mathrm{SO}_{4}\right)_{2}(\mathrm{OH})_{6}\right.$, S.I. $=4.61)$, and kaolinite $\left(\mathrm{Al}_{2} \mathrm{Si}_{2} \mathrm{O}_{5}(\mathrm{OH})_{4}\right.$, S.I. $\left.=2.67\right)$. Recent investigations of other AMD systems have shown that basaluminite (a poorly crystalline form of the mineral felsõbányaite) is the solid phase most likely to buffer dissolved $\mathrm{Al}$ concentrations and $\mathrm{pH}$ in the range of 4 to 5 (Carrero et al. 2017; Sánchez-España et al. 2011). Given that the Berkeley Pit waters are close to saturation with basaluminite now, it is unlikely that $\mathrm{Al}$ concentrations will continue to increase. In fact, as $\mathrm{pH}$ continues to rise due to sludge disposal, it is more likely that large quantities of basaluminite will precipitate out of the water column. The reaction of interest can be written as follows:

$4 \mathrm{AlSO}_{4}^{+}+10 \mathrm{H}_{2} \mathrm{O}=\mathrm{Al}_{4}(\mathrm{OH})_{10} \mathrm{SO}_{4}+3 \mathrm{SO}_{4}^{2-}+10 \mathrm{H}^{+}$.

Considering the high concentration of dissolved $\mathrm{Al}$ (320 $\mathrm{mg} / \mathrm{L}$ or $11.9 \mathrm{mmol} / \mathrm{L})$, Reaction (3) is expected to buffer the $\mathrm{pH}$ of the lake for many years into the future.

\section{Calcium and Sulfate}

Gypsum is a major constituent of sediment in the Berkeley Pit lake (Twidwell et al. 2006), and calculated S.I. values for this mineral have always been close to equilibrium (Davis and Ashenberg 1989; Pellicori et al. 2005; Tucci and Gammons 2015). Samples collected in Nov., 2017 yield gypsum S.I. values of $+0.05 \pm 0.01$ (see Supplemental Information file). Gypsum is also a major component of the lime-treatment sludge. Gypsum precipitation probably accounts for most of the decrease in concentration of dissolved sulfate from $\approx 10,000 \mathrm{mg} / \mathrm{L}$ in 2002 to $\approx 7000 \mathrm{mg} / \mathrm{L}$ in 2017 (Fig. 8b). Some sulfate also would have precipitated as schwertmannite and jarosite. If all of the dissolved $\mathrm{Fe}$ in the pit precipitated as schwertmannite, then a stoichiometric decrease in the $\mathrm{SO}_{4}$ concentration of the water column of $2.8 \mathrm{mmol} / \mathrm{L}$ $\left(\approx 270 \mathrm{mg} / \mathrm{L} \mathrm{SO}_{4}\right)$ would have occurred. This estimate is less than $10 \%$ of the observed decrease in $\mathrm{SO}_{4}$ concentration $(\approx 31 \mathrm{mmol} / \mathrm{L})$, which supports the ideas that gypsum is the main sink for dissolved sulfate in the Berkeley Pit.

To maintain equilibrium with gypsum, one might presume from the common ion effect that a proportional increase in $\mathrm{Ca}^{2+}$ concentration would have occurred as $\mathrm{SO}_{4}{ }^{2-}$ concentrations decreased. However, such an increase has not happened; concentrations of $\mathrm{Ca}$ were $440 \pm 20 \mathrm{mg} / \mathrm{L}$ in 2002 compared to $445 \pm 5 \mathrm{mg} / \mathrm{L}$ in 2017 . The explanation is that much (approximately a third) of the dissolved $\mathrm{SO}_{4}$ in the 2002 pit lake was complexed with dissolved $\mathrm{Fe}$ (II) and $\mathrm{Fe}$ (III) in the form of $\mathrm{FeSO}_{4}(\mathrm{aq})$ and $\mathrm{FeSO}_{4}{ }^{+}$ion pairs. Thus, despite a $30 \%$ decrease in total dissolved $\mathrm{SO}_{4}$ concentration between 2002 and 2017, the concentration of "free" sulfate has remained about the same.

\section{Phosphorus and Arsenic}

The dominant forms of dissolved $\mathrm{P}$ and As in the Berkeley Pit lake are di-protonated phosphate $\left(\mathrm{H}_{2} \mathrm{PO}_{4}{ }^{-}\right)$and arsenate $\left(\mathrm{H}_{2} \mathrm{AsO}_{4}{ }^{-}\right)$. Being anions, both of these species adsorb strongly onto schwertmannite and other hydrous ferric oxides that form at low pH (Dixit and Hering 2003; Manning and Goldberg 1996; Tucci and Gammons 2015). The massive precipitation of ferric precipitates between 2002 and 2017 resulted in almost complete removal of phosphate and arsenate from the water column (Fig. 8c, d). Concentrations of dissolved arsenic in March, 2018 were $10 \pm 3 \mu \mathrm{g} / \mathrm{L}$, essentially equivalent to the U.S. drinking water standard of $10 \mu \mathrm{g} / \mathrm{L}$, and concentrations of dissolved phosphate were below the detection limit of $0.1 \mathrm{mg} / \mathrm{L}$ as P. It is possible that phosphate concentrations are also constrained by precipitation of strengite $\left(\mathrm{FePO}_{4} \cdot 2 \mathrm{H}_{2} \mathrm{O}\right)$, although this cannot be quantitatively evaluated without accurate data on $\mathrm{P}$ concentration and $\mathrm{Fe}(\mathrm{II}) / \mathrm{Fe}$ (III) speciation. The pit-lake water also has very low concentrations of nitrate $(0.3 \mathrm{mg} / \mathrm{L}$ as $\mathrm{N}$, measured in March 2018). Overall, the lake has very low nutrient levels to support growth of algae and other microorganisms.

\section{Other Solutes}

Two other trace elements that have experienced a sharp decrease in concentration during this time frame are vanadium and chromium. In Nov., 2007, $\mathrm{V}$ and $\mathrm{Cr}$ concentrations in the deep pit lake were 241 and $77 \mu \mathrm{g} / \mathrm{L}$, respectively. 


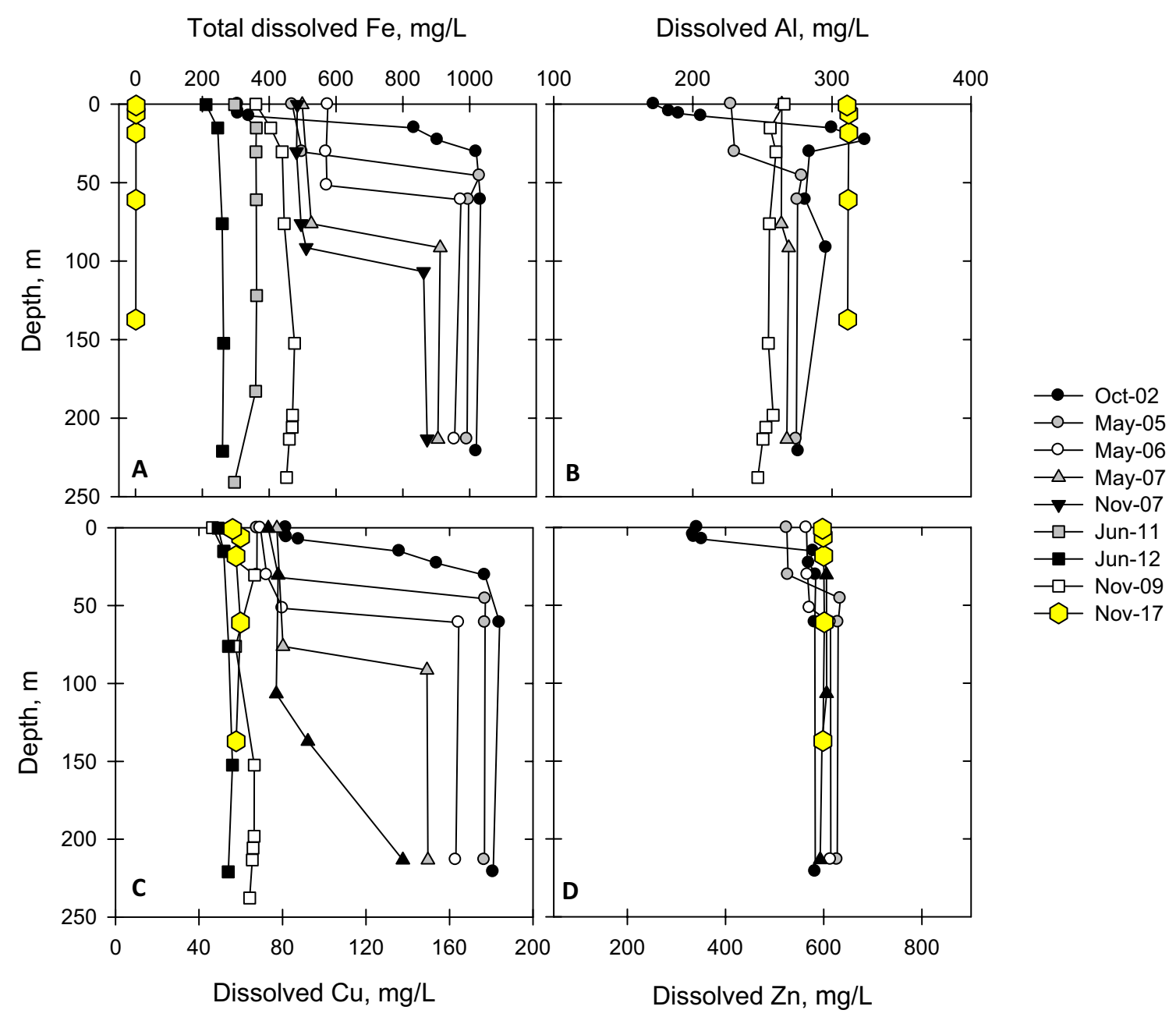

Fig. 7 Changes in the concentrations of dissolved $\mathrm{Fe}, \mathrm{Al}, \mathrm{Cu}$, and $\mathrm{Zn}$ in the Berkeley Pit lake over time

By March 2018, V was below detection $(<1 \mu \mathrm{g} / \mathrm{L})$ and $\mathrm{Cr}$ had dropped to $\approx 6 \mu \mathrm{g} / \mathrm{L}$. At the current Eh and $\mathrm{pH}$ conditions of the Berkeley Pit, dissolved $\mathrm{V}$ most likely occurs as $\mathrm{H}_{2} \mathrm{VO}_{4}^{-}$(Huang et al. 2015), while $\mathrm{Cr}$ could be either hexavalent $\left(\mathrm{HCrO}_{4}^{-}\right)$or trivalent $\left(\mathrm{Cr}^{3+}\right.$ or $\left.\mathrm{Cr}(\mathrm{OH})^{2+}\right)$. Similar to As and $\mathrm{P}$, dissolved $\mathrm{V}$ and $\mathrm{Cr}$ were likely stripped out of the water column by adsorption onto secondary ferric precipitates. A smaller but significant decrease in concentration has occurred for uranium and the rare earth elements (REE). Gammons et al. (2003) reported concentrations of 820 to $880 \mu \mathrm{g} / \mathrm{L} \mathrm{U}, 1050$ to $1170 \mu \mathrm{g} / \mathrm{L} \mathrm{Ce}$ and 480 to $500 \mu \mathrm{g} / \mathrm{L}$ $\mathrm{Nd}$ for pit-lake samples collected at different depths in July 1999, whereas samples collected in March 2018 contained $680 \mu \mathrm{g} / \mathrm{L} \mathrm{U}, 707-737 \mu \mathrm{g} / \mathrm{L} \mathrm{Ce}$, and 300-314 $\mu \mathrm{g} / \mathrm{L} \mathrm{Nd}$ (GWIC 2019). Uranium adsorbs strongly onto hydrous ferric oxide at $\mathrm{pH}>4$ (Waite et al. 1994), and the lanthanides adsorb onto hydrous $\mathrm{Fe}$ or $\mathrm{Al}$ oxides at $\mathrm{pH}>5$ (Ayora et al. 2016; Verplanck et al. 2004). As the pH of the Berkeley Pit continues to rise, it is likely that REE and $U$ will be completely stripped out of the water column by sorption processes. In contrast, concentrations of $\mathrm{Cd}, \mathrm{Co}$, and $\mathrm{Ni}$ have remained essentially unchanged in the past 20 years, averaging $2.0 \pm 0.2,1.7 \pm 0.2$, and $1.2 \pm 0.2 \mathrm{mg} / \mathrm{L}$, respectively. Dissolved Mn values have increased slightly, from about $240 \mathrm{mg} / \mathrm{L}$ in 2002 to about $280 \mathrm{mg} / \mathrm{L}$ in 2018 (GWIC 2019). Other solutes, such as $\mathrm{Mo}, \mathrm{Pb}, \mathrm{Se}$, and $\mathrm{W}$, have insufficient data to discern long-term trends.

\section{Discussion}

\section{Combined Impacts of Copper Recovery and Sludge Disposal}

In a recent paper, Tucci and Gammons (2015) attributed the massive-scale precipitation of ferric solids observed in the Berkeley Pit to the then-active copper recovery circuit, which moved much larger volumes of water (roughly $50 \times 10^{6} \mathrm{~L} /$ day) compared to the volume of sludge (roughly $0.8 \times 10^{6} \mathrm{~L} /$ day). Tucci and Gammons downplayed the 


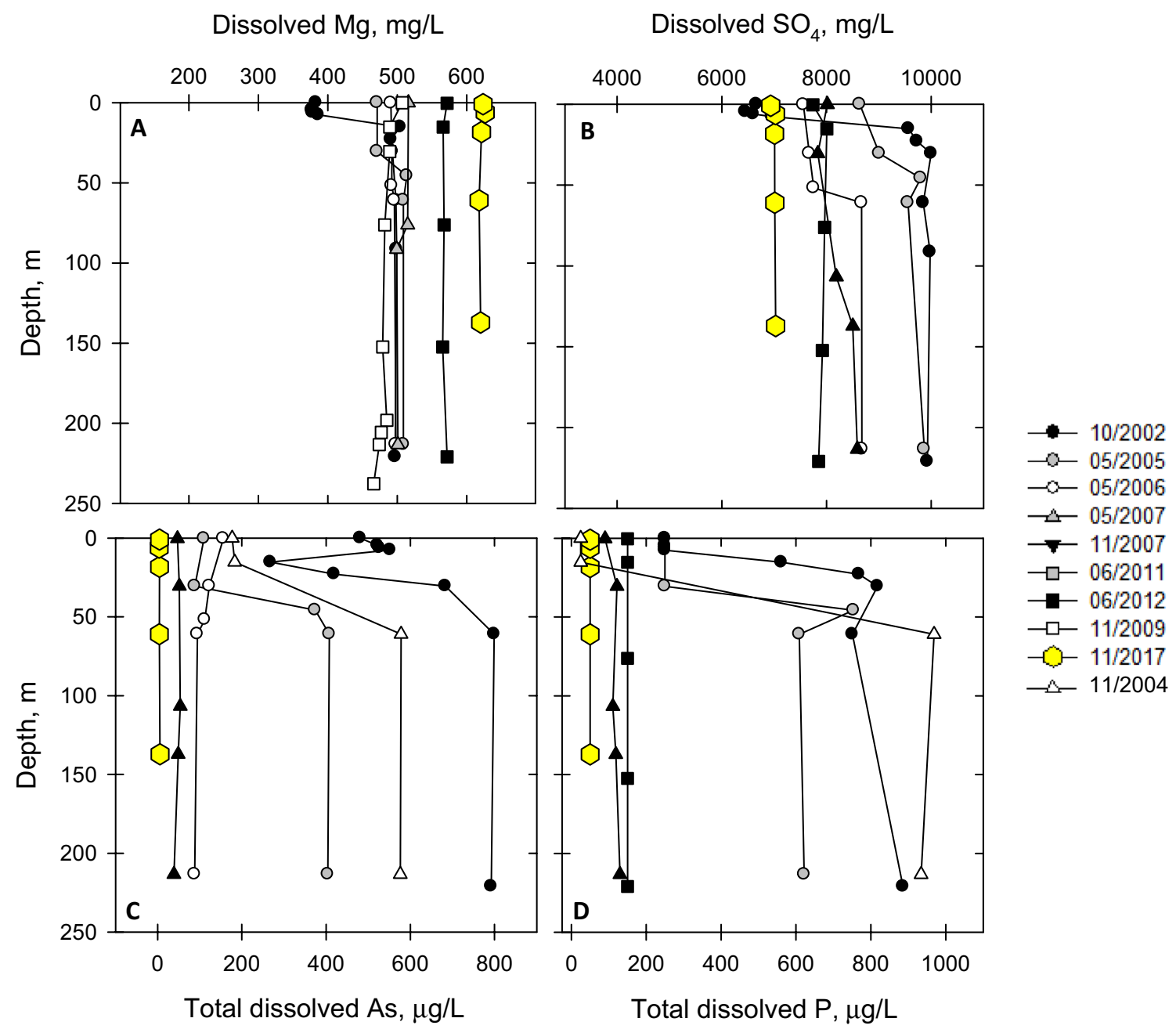

Fig. 8 Changes in the concentrations of dissolved $\mathrm{Mg}, \mathrm{SO}_{4}, \mathrm{As}$, and $\mathrm{P}$ in the Berkeley Pit lake over time

importance of sludge disposal, which was an oversight, as discussed below. To be sure, copper recovery did play a key role in the precipitation of ferric solids by mixing deep water with surface water and allowing complete oxidation of dissolved $\mathrm{Fe}$ (II) to $\mathrm{Fe}$ (III) (e.g., as the $\mathrm{FeSO}_{4}{ }^{+}$ion pair). After oxidation, most of the ferric iron precipitated as schwertmannite or jarosite, via the following reactions:

$$
\begin{aligned}
3 \mathrm{FeSO}_{4}^{+}+\mathrm{K}^{+}+2 \mathrm{SO}_{4}^{2-}+6 \mathrm{H}_{2} \mathrm{O} \\
=\mathrm{KFe}_{3}(\mathrm{OH})_{6}\left(\mathrm{SO}_{4}\right)_{2} \text { (jarosite) } \\
\quad+3 \mathrm{SO}_{4}^{2-}+6 \mathrm{H}^{+}
\end{aligned}
$$

$$
\begin{aligned}
8 & \mathrm{FeSO}_{4}^{+}+1.25 \mathrm{SO}_{4}^{2-}+13.5 \mathrm{H}_{2} \mathrm{O} \\
= & \mathrm{Fe}_{8} \mathrm{O}_{8}(\mathrm{OH})_{5.5}\left(\mathrm{SO}_{4}\right)_{1.25}(\text { schwertmannite }) \\
& +8 \mathrm{SO}_{4}^{2-}+21.5 \mathrm{H}^{+} .
\end{aligned}
$$

Precipitation of jarosite and schwertmannite resulted in a net decrease in total acidity of the water column (9 equivalents on the left side of Reaction 4 vs. 6 on the right; 24 equivalents of acidity on the left side of Reaction 5 vs. 21.5 on the right). Provided these solids do not revert to goethite, this mineral acidity would be stored indefinitely in the sediment at the bottom of the lake (Tucci and Gammons 2015). However, the fact that $\mathrm{pH}$ increased between 2013 and 2018 when the $\mathrm{Cu}$ recovery circuit was not active indicates that oxidation of $\mathrm{Fe}$ (II) and precipitation of ferric solids was not the only reason for the decrease in acidity. Some external source of alkalinity, i.e. the sludge, was needed to drive these reactions to completion and to raise the $\mathrm{pH}$ above 4 .

The disposal of alkaline lime-treatment sludge from the Horseshoe Bend treatment plant into the Berkeley Pit has been continuous from 2003 to the present day. Although the rate of sludge inflow has been small compared to the total volume of the pit lake $\left(>1.6 \times 10^{11} \mathrm{~L}\right)$, the effects 
of its disposal over 15 years have been dramatic. In 2015 alone, the lime-treatment plant consumed $\approx 22,000$ tons $\left(2.0 \times 10^{7} \mathrm{~kg}\right)$ of $\mathrm{CaO}$, with the waste product being a two-stage, high density sludge. The first stage sludge is discharged at a pH in the range of 7 to 7.5 , while the second stage is produced at a $\mathrm{pH}>10.5$ (Montana Resources, Inc., pers. commun.). Data on the chemical composition of each sludge are included in the Supplemental Information file, along with x-ray diffraction (XRD) data. Based on XRD, the dominant crystalline phase in the sludge is gypsum. The elements $\mathrm{Al}, \mathrm{Cu}, \mathrm{Fe}, \mathrm{Mg}, \mathrm{Mn}$, and $\mathrm{Zn}$ are believed to be present as poorly crystalline hydroxides, possibly layered double hydroxides (Boclair and Braterman 1999) of the type $\mathrm{M}(\mathrm{II})(\mathrm{OH})_{2-\mathrm{x}} \mathrm{M}(\mathrm{III})(\mathrm{OH})_{3}\left(\mathrm{SO}_{4}\right)_{\mathrm{x} / 2}$ where $\mathrm{M}(\mathrm{II})$ is $\mathrm{Cu}^{2+}, \mathrm{Fe}^{2+}, \mathrm{Mg}^{2+}, \mathrm{Mn}^{2+}, \mathrm{Zn}^{2+}$, and $\mathrm{M}$ (III) is $\mathrm{Al}^{3+}$ or $\mathrm{Fe}^{3+}$. A laboratory titration of the combined Stage 1 and Stage 2 sludge with $0.2 \mathrm{~N} \mathrm{H}_{2} \mathrm{SO}_{4}$ to a $\mathrm{pH}$ endpoint of 2.5 indicated an alkalinity of almost exactly $1 \mathrm{eq} / \mathrm{kg}$, or $1.14 \mathrm{eq} / \mathrm{L}$ (the sludge has a measured density of $1.12 \mathrm{~g} / \mathrm{mL}$; MBMG, unpublished data). This agrees with mass balance calculations made by combining the known mass of lime added at the treatment plant (e.g. $4.74 \times 10^{6} \mathrm{~kg}$ in the first quarter of 2015) and the sludge volume discharged $\left(1.63 \times 10^{8} \mathrm{~L}\right.$ in the same time period).

At the $\mathrm{pH}$ endpoint of the lime treatment process $(\approx 11)$, the contribution to total alkalinity from molecules that remain in solution, such as $\mathrm{CO}_{3}{ }^{2-}$ or $\mathrm{OH}^{-}$, is very small (about $3 \mathrm{meq} / \mathrm{L}$, or $0.3 \%$ of the total alkalinity). Most of the alkalinity in the sludge is stored as precipitated metals ( $\mathrm{Fe}, \mathrm{Al}, \mathrm{Zn}, \mathrm{Mn}, \mathrm{Cu}, \mathrm{Mg}$, etc....) in the form of amorphous hydroxides or other poorly crystalline phases. After disposal into the acidic pit lake, some of the solids in the sludge redissolve, releasing their "mineral alkalinity" back to the waters:

$\mathrm{Me}(\mathrm{OH})_{\mathrm{x}}=\mathrm{Me}^{\mathrm{x}+}+\mathrm{xOH}^{-}$.

where Me is any of the various metals in the sludge, and $\mathrm{x}$ is either 2 or 3. However, not all of the solid hydroxides would have redissolved into the pit lake. For example, at the present $\mathrm{pH}(\approx 4.1)$ of the Berkeley Pit, ferric hydroxide will remain insoluble, or will convert to another phase (e.g. jarosite or schwertmannite).

If we assume a constant rate of lime use over 15 years, the Horseshoe Bend plant consumed roughly $3 \times 10^{8} \mathrm{~kg}$ of lime, which equates to $1.1 \times 10^{10}$ moles of alkalinity ( 2 mol of alkalinity per mole of $\mathrm{CaO}$ ). Assuming a total lake volume of $1.6 \times 10^{11} \mathrm{~L}$ and an average total acidity for the pre-2003 water column of $0.1 \mathrm{~mol} / \mathrm{L}$ (Fig. $5 \mathrm{c}$; see also Tucci and Gammons 2015), there would have been around $1.6 \times 10^{10} \mathrm{~mol}$ of total acidity in the pit prior to interaction with the sludge. If all of the alkalinity in the lime wound up being stored as solid particles in sludge, and if these solids completely dissolved after disposal into the pit, then roughly two-thirds of the acidity of the pit lake could have been neutralized in 15 years. However, as stated above, some fraction of the sludge, in particular the ferric hydroxide, would not have reacted. Based on historical trends (Fig. 5c), the total acidity of the Berkeley Pit has actually dropped by roughly $35 \%$ to $40 \%$ in the period 2003 to 2018.

Because the flux of sludge into the pit has been more or less constant since 2003, the drop in acidity has been more or less linear (Fig. 5c). In contrast, the $\mathrm{pH}$ of the lake hardly changed between 2003 and 2013 (Fig. 5a). The constancy in $\mathrm{pH}$ is explained by the strong buffering effect of dissolved ferric iron precipitating as schwertmannite and jarosite (Reactions 4, 5; see also Nordstrom and Campbell 2014). Once most of the dissolved ferric iron was titrated out of the water column, the $\mathrm{pH}$ of the pit lake rose rapidly to $>4$, and the lake shifted from being Fe-controlled to being Alcontrolled (Reaction 3). Inconveniently, much of the rise in pH occurred between 2012 and 2017, when monitoring was suspended for safety reasons.

\section{What Lies Ahead?}

The long-term remedial plan for the Berkeley Pit is to pump and treat the water to maintain a water elevation (critical water level) below the lowest point in the local groundwater/ surface water system to prevent the spread of contamination (EPA 2016). At the current filling rate of 10.8 million L/day, the critical water level will be reached in 2023. In anticipation of this, and to assess various treatment options, pumping and treating of Berkeley Pit water will begin in 2019. Water pumped from the Berkeley Pit will be treated at the lime-treatment plant currently treating Horseshoe Bend (HSB) water and the HSB water will be diverted to the active tailings pond. Because the current chemistry of the Berkeley Pit is different than the HSB chemistry, the sludge discharged to the pit will be different. The character of the sludge, and its potential impact on the future chemistry of Berkeley Pit, will depend on the treatment systems that are currently being assessed.

Although mine-water management of the Berkeley Pit has resulted in significant decreases in acidity, increases in $\mathrm{pH}$, and decreases in dissolved arsenic, it is unlikely that concentrations of other toxic metals (e.g. $\mathrm{Cd}, \mathrm{Cu}, \mathrm{Zn}$ ) will drop in the near future. The $\mathrm{pH}$ of the lake is presently buffered by precipitation of basaluminite (Reaction 3 ) or some other hydrous $\mathrm{Al}$ phase. It could take 10 years or more to titrate all of the dissolved $\mathrm{Al}$ out of the lake at current rates of sludge disposal. Once the $\mathrm{Al}$ is removed, $\mathrm{pH}$ is expected to rise to the next buffer, which could involve precipitation of $\mathrm{Cu}$ or $\mathrm{Zn}$ as hydroxide or mixed hydroxy-sulfate-carbonate minerals (e.g. brochantite, hydrozincite). For the foreseeable 
future, discouraging exposure of wildlife (e.g. migratory waterfowl) to the lake via hazing will remain a priority.

\section{Conclusions}

In the past 15 years, the total acidity of the Berkeley Pit has dropped by more than a third, the $\mathrm{pH}$ has increased from $\approx 2.5$ to $>4.0$, and the total dissolved Fe concentrations have plummeted from $\approx 1000 \mathrm{mg} / \mathrm{L}$ to $<5 \mathrm{mg} / \mathrm{L}$. These changes were the result of two processes: (1) Cu recovery, which completely mixed the lake and allowed oxidation of $\mathrm{Fe}(\mathrm{II})$ to $\mathrm{Fe}(\mathrm{III})$; and (2) sludge disposal, which neutralized the "iron acidity" released by precipitation of schwertmannite and other ferric solids. With Fe removed, the $\mathrm{pH}$ of the lake quickly rose to values $>4.0$ where it is presently buffered by precipitation of hydrous $\mathrm{Al}$ phases. Other solutes have experienced decreases in concentrations (e.g. As, $\mathrm{P}, \mathrm{V}, \mathrm{Cr}, \mathrm{SO}_{4}$ ), increases in concentrations (e.g. $\mathrm{Mg}, \mathrm{Mn}$ ), or negligible change (e.g. $\mathrm{Ca}, \mathrm{Cd}, \mathrm{Co}, \mathrm{Ni}, \mathrm{Zn}$ ). In the past 2 years of monitoring, DO concentrations have been poised near $6 \mathrm{mg} / \mathrm{L}$ at all depths. The lake is presently holomictic, with seasonal mixing driven by wind events.

To pit-lake researchers, it may be heartening to consider that the Berkeley Pit is not an entirely hopeless case. The chemistry of the pit has improved in the past 15 years and future changes in treatment processes and water management may result in yet more changes. Although pumping and lime treatment will continue for decades (if not centuries), the slow but steady drop in acidity due to sludge disposal should translate into gradual water-quality improvement and a decrease in annual lime-consumption costs. Whether or not the chemistry of the lake will ever improve to the point where treatment could be safely discontinued is not known at this time.

Open Access This article is licensed under a Creative Commons Attribution 4.0 International License, which permits use, sharing, adaptation, distribution and reproduction in any medium or format, as long as you give appropriate credit to the original author(s) and the source, provide a link to the Creative Commons licence, and indicate if changes were made. The images or other third party material in this article are included in the article's Creative Commons licence, unless indicated otherwise in a credit line to the material. If material is not included in the article's Creative Commons licence and your intended use is not permitted by statutory regulation or exceeds the permitted use, you will need to obtain permission directly from the copyright holder. To view a copy of this licence, visit http://creativecommons.org/licenses/by/4.0/.

\section{References}

Allison JD, Brown DS, Novo-Gradac KJ (1991) MINTEQA2/PRODEFA2, a geochemical assessment model for environmental systems. US EPA/600/3-91/021
Ayora C, Macías F, Torres E, Lozano A, Carrero S, Nieto JM, PérezLópez R, Fernández-Martinez A, Castillo-Michel H (2016) Recovery of rare earth elements and yttrium from passiveremediation systems of acid mine drainage. Environ Sci Technol 50:8255-8262

Blanchette ML, Lund MA (2016) Pit lakes are a global legacy of mining: an integrated approach to achieving sustainable ecosystems and value for communities. Curr Opin Environ Sust 23:28-34

Boclair JW, Braterman PS (1999) Layered double hydroxide stability. 1. Relative stabilities of layered double hydroxides and their simple counterparts. Chem Mater 11:298-302

Carrero S, Fernandez-Martinez A, Pérez-López R, Nieto JM (2017) Basaluminite structure and its environmental implications. Procedia Earth Planet Sci 17:237-240

Castendyk DN, Eary LE (eds) (2009) Mine pit lakes: characteristics, predictive modeling, and sustainability. Soc for Mining, Metallurgy, and Exploration, Littleton

Castro JM, Moore JN (2000) Pit lakes: their characteristics and the potential for their remediation. Environ Geol 39:1254-1260

Davis A, Ashenberg D (1989) The aqueous geochemistry of the Berkeley Pit, Butte, Montana, USA. Appl Geochem 44:23-36

Davis A, Eary LE (1997) Pit lake water quality in the western United States: an analysis of chemogenetic trends. Min Eng 49:98-102

Dixit S, Hering JG (2003) Comparison of arsenic(V) and arsenic(III) sorption onto iron oxide minerals: implications for arsenic mobility. Environ Sci Technol 37:4182-4189

Duaime TE, McGrath SF (2019) Butte Montana: the Berkeley Pit, changes in water quality and water sampling methods, 1982-2017. Bull 138, Montana Bureau of Mines and Geology

Duaime TE, Metesh JJ, Kerschen MD, Dunstan CB (1998) The flooding of Butte mines and Berkeley Pit. Open-File Rept 376, Montana Bureau of Mines and Geology

Duaime TE, Icopini GA, McGrath SF, Thale PR (2016) Butte underground mines and Berkeley Pit, water-level monitoring and waterquality sampling, 2015 Consent Decree update, Butte, Montana, 1982-2015. Open-File Rept 676, Montana Bureau of Mines and Geology

Duaime TE, McGrath SF, Icopini GA, Thale PR (2018) Butte mine flooding operable unit, water-level monitoring and water-quality sampling 2016 consent decree update, Butte, Montana 1982-2016. Open-File Rept 700, Montana Bureau of Mines and Geology

Duaime TE, McGrath SF, Icopini GA, Thale PR (2019) Butte mine flooding operable unit water-level monitoring and water-quality sampling 2017 consent decree update, Butte, Montana, 1982-2017. Open-File Rept 709, Montana Bureau of Mines and Geology

Dzombak DA, Morel F (1990) Surface complexation modeling: hydrous ferric oxide. Wiley, New York City

EPA (2016) Fourth five-year review report for Silver Bow Creek/Butte area superfund site. 1551629-R8 SDMS, US Environmental Protection Agency. EPA, Washington

Gammons CH, Duaime TE (2006) Long-term changes in the geochemistry and limnology of the Berkeley pit-lake, Butte, Montana. Mine Water Environ 25:76-85

Gammons CH, Wood SA, Jonas JP, Madison JP (2003) Geochemistry of rare earth elements and uranium in the acidic Berkeley Pit lake, Butte, Montana. Chem Geol 198:269-288

Gammons CH, Harris LN, Castro JM, Cott PA, Hanna BW (2009a) Creating lakes from open pit mines: processes and considerations, with emphasis on northern environments. Canadian Technical Report of Fisheries and Aquatic Sciences 2826

Gammons CH, Snyder DM, Poulson SR, Petritz K (2009b) Geochemistry and stable isotopes of the flooded underground mine workings of Butte, Montana. Econ Geol 104:1213-1234 
Geller W, Schultze M, Kleinmann R, Wolkersdorfer CE (eds) (2013) Acidic mining lakes: the legacy of coal and metal surface mines. Springer, Berlin

Gustafsson JP (2012) Visual MINTEQ, v. 3.0, KTH, Dept Land Water Resources Eng, Stockholm, Sweden. https://vminteq.lwr.kth.se/

GWIC (2019) Montana Bureau of Mines and Geology, Groundwater Information Center. http://mbmggwic.mtech.edu/

Hill B, Cote P, Leishman W, Alangari A, Erickson M, Holliday T, Ellertson C, Fricks T, Duaime TE, Icopini GA (2018) Unmanned partially autonomous boat for profiling and sampling the Berkeley Pit.In: Proceedings of the 11th International Conference for Remediation Chlorinated Recalcitrant Compounds, Palm Springs, CA

Huang JH, Huang F, Evans L, Glasauer S (2015) Vanadium: global (bio)geochemistry. Chem Geol 417:68-89

Manning BA, Goldberg S (1996) Modeling competitive adsorption of arsenate with phosphate and molybdate on oxide minerals. Soil Sci Soc Am J 60:121-131

McGivern A (2014) Geochemistry and stable isotopes of surface water and groundwater in the Continental Pit in Butte, Montana, USA. Montana Tech Graduate Theses and Non-theses: https://digit alcommons.mtech.edu/grad_rsch/3/

Miller GC, Lyons WB, Davis A (1996) Understanding the water quality of pit lakes. Environ Sci Technol 30:118A-123A

Nordstrom DK, Campbell KM (2014) Modeling low-temperature geochemical processes. In: Drever JI (ed) Surface and Ground Water, Weathering, and Soils, Treatise on Geochemistry. Elsevier, New York, pp 27-68

Pellicori DA, Gammons CH, Poulson SR (2005) Geochemistry and stable isotope composition of the Berkeley pit lake and surrounding mine waters, Butte, Montana. Appl Geochem 20:2116-2137

Robbins J (2016) Hordes of geese die on a toxic lake in Montana. New York Times https://www.nytimes.com/2016/12/12/science/snowgeese-deaths-montana.html Accessed 12 Dec 2016.
Sánchez-España J, Yista I, Diez-Ercilla M (2011) Schwertmannite and hydrobasaluminite: a re-evaluation of their solubility and control on the iron and aluminum concentration in acidic pit lakes. Appl Geochem 26:1752-1774

Sonderegger JL, Duaime TE, Noble RA, Ohguchi T (1987) Butte mine flooding and the Berkeley Pit. Open File 195, Montana Bureau of Mines and Geology

Soni A, Mishra B, Singh S (2014) Pit lakes as an end use of mining: a review. J Mining Environ 5:99-111

Stierle AA, Stierle DB (2013) Bioprospecting in the Berkeley Pit: the use of signal transduction enzyme inhibition assays to isolate bioactive secondary metabolites from the extremophilic fungi of an acid mine waste lake. Stud Natl Prod Chem 39:1-45

Swedlund PJ, Webster JG (2001) Cu and Zn ternary surface complex formation with $\mathrm{SO}_{4}$ on ferrihydrite and schwertmannite. Appl Geochem 16:503-511

Tucci NJ, Gammons CH (2015) Influence of copper recovery on the water quality of the acidic Berkeley Pit lake, Montana, USA. Environ Sci Technol 49:4081-4088

Twidwell L, Gammons CH, Young C, Berg R (2006) Deepwater sediment/pore water characterization of the metal-laden Berkeley pit lake in Butte, Montana. Mine Water Environ 25:86-92

Verplanck PL, Nordstrom DK, Taylor HE, Kimball BA (2004) Rare earth element partitioning between hydrous ferric oxides and acid mine water during iron oxidation. Appl Geochem 19:1339-1354

Waite TD, Davis JA, Payne TE, Waychunas GA, Xu N (1994) Uranium (VI) adsorption to ferrihydrite: application of a surface complexation model. Geochim Cosmochim Acta 58:5465-5478 